\title{
Potential for Waste to Energy Generation of Municipal Solid Waste (MSW)in the Kumasi Metropolis of Ghana
}

Purpose: Globally, waste management has been a topical issue in the last few decades due to continual increase in municipal solid waste generation that is becoming difficult to handle with the conventional waste management techniques. The situation is much more pronounced in economically developing countries where population growth rate and urbanization are becoming uncontrollable. The aim of this study was to assess the potential for waste to energy generation in the Kumasi Metropolis, the second largest city in Ghana.

Methodology: To address the objectives of the study, a quantitative research approach viz questionnaire was adopted. The data analysis was done using the Statistical Package for Social Sciences (SPSS version 25), including both descriptive and inferential statistics to give an in-dept meaning to the responses from the participants.

Findings: The results showed that several factors hinder waste to energy technology in Ghana; key among them were high capital cost, high operational cost and lack of governmental support and policy framework. The results also revealed that $1 \mathrm{~m}^{3}$ of biogas generated from Municipal Solid Waste (MSW) in Kumasi could generate 36MJ of energy, equivalent to $10 \mathrm{~kW} / \mathrm{h}$.

Originality: The unique contribution made by the paper is that it combines expert opinions, empirical data that included time series data and opinion of key actors in the waste management chain in assessing the potential for waste to energy generation in the Kumasi Metropolis of Ghana.

Keywords: Municipal Solid Waste (MSW), Waste Management, Waste to Energy, Biogas, Energy Potential, Kumasi Metropolis, Landfill

\section{Introduction}

Waste management is a serious problem in most African countries particularly in the cities due to the generation of huge mountains (heaps) of waste as a result of rapid urban population (Agbelie et al., 2015). The generation of waste in Africa is expected to grow exponentially in the near future (Agbelie et al., 2015). Economic Commission for Africa [ECA] (2009), corroborated the fact that urbanisation is rising steadily in Africa and it has created the problem of waste management faced on the continent. The constraints in capacity faced in the management of waste in Africa are expected to aggravate due to urbanisation, industrialisation and modernisation of agriculture in Africa (ECA, 2009). The modernisation in the agricultural sector is also expected to contribute to the growth of waste generation in Africa significantly (ECA, 2009). According to Bello et al. (2016), globalization has increased waste generation in Africa tremendously, and there is therefore the need for concerted effort to salvage the trend. Africa faces numerous challenges in waste management. City Authorities in Africa face a lot of challenges managing generated waste due to lack of resource allocation from their governments (Agbelie et al., 2015). According to ECA (2009), about half of the waste generated in Africa is left uncollected and it is left in urban dumping landscape. Improper waste management has dire consequences on our environment including providing a breeding place for mosquito leading to the spread of malaria (Bawakyillenuo and Agbelie, 2014). These problems are most common in African countries. According to United Nations Habitat [UN-Habitat] (2014), waste management is a difficult situation in most African 
Countries. It is also a key indicator resulting in the inability of most African countries to meet the Millennium Development Goals (MDGs) on sanitation and slums (UN-HABITAT, 2014). Gomaa et al. (2020) developed a solar reactor that couples both renewable and a conventional energy sources to produce synthesis gas (syngas) via the utilization of solar energy as a heat source for the co-gasification process of biomass and coal in a solar gasifier during high and low solar irradiation, and making use of the same gasifier to work during no solar radiation, through develop a solar gasifier that can hold both solar and autothermal types of gasification processes. Gomaa $e t$ al. (2020) confirmed their study by using a co-gasification process, the properties of coal are improved and can, therefore, be tailored to consumer demands for renewable energy.

Ghana, as a developing country has fairly faced its share of the waste management problem due to increased population growth and urbanization resulting in the generation of volumes of waste in our cities particularly Accra and Kumasi. Accra as at 1999 generated 1,000 tons of waste per day with an estimated annual generation rate of $\left(3.7 \times 10^{4}\right)$ tons per year (Fobil, 2002). With the estimated generation rate, the city could only collect $55 \%$ of all the tons of waste generated per year (Fobil, 2002). This presupposes that about $\left(1.7 \times 10^{4}\right)$ tons of waste per year were left uncollected and allowed to accumulate in strategic locations of the city for months (Fobil, 2002).Exploring strategic solutions for the effective and efficient management of waste in the two biggest cities in Ghana namely Kumasi and Accra are top priorities for Governments of Ghana (Agbelie et al., 2015). The waste generation capacity in Accra alone increased steadily to 2,800 metric tons of municipal solid waste per day (Bawakyillenuo and Agbelie, 2014). According to Bawakyillenuo and Agbelie (2014)' about 2,200 tons of the waste is collected leaving a backlog of 600 tons which is left in the city causing choked gutters leading to flooding annually. Pursuant to this revelation, Accra has been described as a city engulfed by waste and filth (Obour, 2012).

Several studies conducted in Ghana have shown that there is a great potential for energy generation from waste produced in the country (Duku et al., 2011a, Ofori-Boateng, 2013; Mohammed et al., 2013; Kemausuor et al., 2014; Ulrike et al., 2014; Gyamfi et al., 2015; Danquah et al., 2018; Akolgo et al., 2018; Acheampong et al., 2018), as well as recent studies conducted in developed countries (Gomaa et al., 2020, Gomaa et al., 2020). This notwithstanding, the country is yet to explore or implement any comprehensive waste to energy generation system to harness this potential (Ofori, 2016). Even though, there has been a growing need for industries to generate and use energy from the waste they produce in the face of a burgeoning low electricity production, little exploit has been made out of these calls. Ghana's economy relies heavily on petroleum as the major source of energy. There is yet very little variation in the energy mix of the country to include sustainable renewable energy sources. As a result of this, any difficulty in the generation or purchase of petroleum products to fuel energy generation plants take a serious toll on electricity production and the economy of the country at large. Against this backdrop, many researchers are increasingly realising that, waste to energy generation could be the most sustainable solution to the twin problems in waste management and the generation of electricity in the country (OforiBoateng et al., 2013). Not only will waste to energy approaches serve as a sustainable waste management strategy but it will also reduce greenhouse emissions, while opening up opportunities in the transport sector through the use of biogas as vehicle fuel and reducing national grid peak load. The aim of the study was to assess the potential for energy generation from Municipal Solid Waste collected in the Kumasi Metropolis in the Ashanti Region of Ghana. The specific objectives of the study include; to identify the factors that hinder waste to energy generation in the Kumasi Metropolis; to determine the characteristics of MSW and disposal methods used in the Kumasi Metropolis and to examine the energy potential of MSW collected in the Kumasi Metropolis .This 
study is necessitated by the burgeoning energy crisis that is negatively affecting the economy of Ghana and the impasse in the management of municipal waste especially in the cities of Ghana. The study sought to bring to the attention of policy makers and stakeholders in both the energy sector and waste management organizations the synergy of combining waste management practices and energy generation as sustainable solution to Ghana's energy crisis. The finding of the study will thus rekindle the interest of government and other stakeholders as well as private individuals about the opportunities in waste to energy generation in the country.

\section{Towards Circular Economy: The Need for Waste to Energy Generation}

Value has been placed on waste due to the emphasis on the need to reduce, re-use, recycle and recover as well as the continuous growth in the cost associated with waste disposal. The Circular Economy concept is based on the principle of using waste as resource in alleviating poverty. Rather than, throwing away the waste because it is not needed, the circular economy takes the waste and make new products out of the waste. According to Peralla (2011), close to $80 \%$ of products get discarded within six (6) months of leaving the production companies. It is important to note that, turning waste to means of resource for poverty alleviation in developing countries by the application of The Circular Economy is urgently needed. It is estimated that, about trillion dollars and close to 100,000 jobs can be added to the economy of any country that implements the circular economy concepts by turning waste as a resource for poverty alleviation by 2025 (Perella, 2014). Most developing countries face the problem of huge unemployment and difficulty in appropriately managing waste generated. It is therefore compelling to promote the development of their economies by turning waste as resource for poverty alleviation and create the needed jobs for their citizens. The transformation of waste to energy has transcended beyond waste management and needs to be embedded in a wider framework in the circular economy (Chibinda, 2016). The need to transition to a more circular economy is recognized as an essential element in developing a sustainable, low carbon, resource efficient and competitive economy (European Union, 2017). Using the concepts of circularity helps progression towards a sustainable future (Chibinda, 2016). There is global demand in the midst of finite availability of renewable and non-renewable energy. Central to the theory of circular economy is the principle that materials and products are kept as high as possible as long as possible. This helps to minimise the need for the input of new material and energy, thereby reducing environmental pressure linked to the life-cycle of products, from resource extraction, through production and use to end-of-life (European Union, 2017).

\section{Psychology of Waste to Energy Generation}

Waste to energy can simply be described as the concept or process of converting or generating energy from commercial and industrial waste, agricultural by-products, animal manure, as well as Municipal Solid Waste which are not recyclable (Ofori, 2016). According to Ofori (2016), generation of energy from waste also enhances sustainable waste management by avoiding the emission of methane which is typical with landfilling. Waste to energy provides a better alternate means of offsetting greenhouse emission. Ragossnig et al. (2008) also opined that, generation of energy from waste through the practice of reducing methane emissions at landfills sites impacts positively on global climate change. This is because, when energy is generated from waste, the use of fossil fuels is reduced due to the use of the by-products of the process such as biogas and bio- 
charcoal for cooling and heating. Landfills generate methane; therefore, there are a lot of benefits in reducing methane emission by flaring methane for energy generation. According to Agbelie et al. (2015) there are basically two technological means of generating energy from waste; Incineration and collection of methane. Ofori (2016) contend that, gasification, incineration or combustion, Landfills Gas Recovery (LFGR) as well as anaerobic digestion are basic ways of generating energy from waste. There is no one sure best technology for generating energy from waste, as such many municipal authorities combine the basic ways to achieve it (Agbelie et al., 2015). The Environmental Services Association (2013) provides detailed pathways of waste management options as well as technologies in African countries. Ofori (2016) defines incineration/combustion as the thermal process used in generating energy from waste through complete oxidation by converting solid waste into gaseous, liquid, and solid products under high pressure through burning. The energy generated at the end of the incineration process is used as electricity due to the fact that, heat energy is the end product of combustion. The process of incineration or combustion produces about $90 \%$ of biomass energy (International energy agency [IEA], 2007). The process of incineration has very less environmental impact due to the about $90 \%$ efficiency of the boiler and combustion technology (Leskens et al., 2005) as a result of the efficiency of the certified biomass technology (Demirbas, 2005; Obemberger, 2009). According to Obemberger (2009), the process of incineration is far better than gasification.

The process of converting organic waste to biogas is done through the use of Anaerobic Digestion with feedstock in the digester (Ofori, 2016). The decomposition of the organic waste in the presence of microorganism at a temperature of 55 to 60 degrees Celsius without the presence of air produces the biogas. Due to the correlation between the methane content and the energy generated, analysis of the waste before the process of Anaerobic Digestion is essential (Ulrike et al., 2014). The organic waste needed for the Anaerobic Digestion can be the Municipal Solid Waste, Plants residue, animal manure as well as commercial and industrial waste. The remains at the end of the anaerobic digestion contain high level of nitrogen which is suitable for use as fertilizer (Ramachandra, 2008). The process of landfill gas recovery is synonymous to that of anaerobic digestion except that, in the anaerobic digestion, there is the control of the organic decomposition. The decomposition of the organic waste by the microorganism releases two gases; carbon dioxide and methane (Agbelie et al., 2015). The methane captured is converted to water and carbon dioxide when the gas is burned to produce electricity or heat.

\section{Theoretical and Empirical Review}

Several works have been conducted on the potential of waste to energy technologies in Ghana. Arthur et al. (2011) revealed that the use of animal manure which contains calorific value of 22.5 $\mathrm{MJ} / \mathrm{m}^{3}$, can produce 350 million $\mathrm{m}^{3}$ of biogas an equivalent of $2100 \mathrm{GWh}$ or $7875,000 \mathrm{GJ}$. In addition, 360,000 tonnes of liquid fertilizer can be produced from animal manure annually which can be used for 70, 000 hectares of farm based on irrigation or dry farming of 140, 000 hectares (Bensah and Brew-Hammond, 2010). Mohammed et al. (2013) showed that, in rural communities, it is more efficient to use gasification for combined heat and power to generate energy from waste. Bio-charcoal can even be obtained if such method is adopted (Duku et al., 2011a). According to Ramachandra (2008), $740 \mathrm{~kg}$ of animal dung, $88 \mathrm{~kg}$ of charcoal, 37 Liters of kerosene, $26 \mathrm{~kg}$ of LPG and $210 \mathrm{~kg}$ of wood fuel can be replaced with $2 \mathrm{~m}^{3}$ biogas to generate heat. Several researches have been conducted on the production of bioenergy, which comprehensively assessed the availability of biomass in Ghana (Duku et al., 2011; Kemausuor et al., 2014). Kemausuor et al. 
(2014) further listed other sources which included municipal solid waste, waste residue and animal waste. Ulrike et al. (2014) also assessed the electricity potential and heat energy potential. Kemausuor et al. (2014) upon technical and potential assessment estimated 96 PJ of bioenergy can be obtained from $2700 \mathrm{Mm}^{3}$ of biogas. Though, the electricity potential estimates were carried out by Ulrike et al. (2014), no estimation was done on the availability of the electricity for home and industrial use.

Generating energy from waste does not only present a better waste management (Ofori-Boateng et al., 2013) but it also provide an avenue for economic activities leading to the creation of substantial employment and jobs (Menikpura et al., 2016) as well as providing an opportunity for women to spend ample time with their family (International Renewable Energy [IRENA], 2015).The challenges of electricity shortages in most remote and rural communities in Ghana can be curtailed if the country localized the generation of energy from waste (Ackom, 2013; Mohammed et al., 2013). The localization of the waste to energy technology in rural communities does not only solve the power scarcity but it also opens up economic opportunities leading to job creation.

There is non-existence of data on municipal solid waste in Ghana. However, a survey conducted by Meiza et al. (2015) revealed $0.47 \mathrm{~kg}$ rate of waste is generated per person per day in Ghana. Ghana's current population stands at 27,043,093 (Ghana Statistical Service, 2014), which means that 12,710 tons of waste is generated daily in Ghana. The potential of waste to energy industry in Ghana is very high because the content of waste generated in Ghana has a higher percentage of organic materials (Ofori, 2016). Nonetheless, for such industry to be successful in Ghana, the public must be made aware to sort their waste. Thailand is a beacon of hope in waste to energy technology. The municipal solid waste generated in Thailand has $48 \%$ organic content according to the World Bank (2012). Asase et al. (2009) and Meiza et al. (2015) report that, the municipal solid waste generated in Ghana has an organic content ranging between $61 \%$ and $64 \%$. This means that, potentially Ghana is more viable for waste to energy technology than Thailand.

Arthur et al. (2011) presents five (5) main potentials for biogas or waste to energy generation in Ghana namely; Agricultural benefits, health benefits, benefits of employment generation, environmental benefits and women empowerment and workload reduction. The agricultural sector has played a pivotal role in the economic development of Ghana. Most farmers in Ghana rely on manure as fertilizer; as such the waste to energy technology would help produce manure which could help stop the importation of fertilizer thereby stabilizing the economy (Arthur et al., 2011). Most homes in Ghana use wood fuel as their source of energy for cooking which produces smoke into the environment; therefore, causing acute respiratory infections (Niwagaba, 2007). Waste to energy technology can produce biogas which is safe for cooking. Waste to energy technology can a create a lot of employment opportunities along the supply chain. One major problem faced by metropolitan, municipal and district assemblies are improper disposal of waste and inadequate landfill sites (Arthur et al., 2011). Such problems can be solved with waste to energy industry. In homes in Ghana, the responsibility of cooking is on the women and they therefore have the responsibility of looking for charcoal and wood fuel; the introduction of waste to energy would release them of such burden (Energy Commission, 2006).

Starchy food crops such as maize, cassava, yam, cowpea, potatoes, groundnut as well as sugar crops like sugar cane are in large volumes in Ghana which makes the country the best in terms of huge production of ethanol (Ofori, 2016) .Crop and animal waste are also available for electricity through the process of anaerobic digestion. According to Ofori (2016) crops and forestry products 
in Ghana are rich in lignocellulose which have high methane content and therefore produce biogas of high quality.

\section{Methodology}

The positivist/objectivist philosophy was adopted for this study as it allows the researcher to assess the potential for waste to energy generation in the Kumasi Metropolis using quantifiable observations that lead to statistical analysis. By the nature of this study, the quantitative approach was employed. Mack et al. (2005) opined that quantitative research approach should be used when a study seeks to confirm hypotheses or theory on a particular phenomenon using empirical data. As a study that is quantitative in nature, the deductive research approach was employed. The population of the study included all staff and management under the Waste Management Department of the Kuamsi Metropolitan Assembly [KMA], staff and management of Zoomlion Ghana Limited, individual waste collectors and staff from the Energy Centre of the Kwame Nkrumah University of Science and Technology. The target population of the study was therefore 104 individuals comprising of 16 staffs of Zoomlion Ghana limited, five (5) staff of the KMA waste management division working at the Landfill site and 83 individual wastes collectors.

In this study, the Kish (1995) approach was used in determining the sample size. The approach is most appropriate when there is an available sample frame as it is in the case of this study. The generic formula for this approach is:

$n=\frac{N}{\left[1+N(\alpha)^{2}\right]}$

Where $\mathrm{n}=$ sample size,

$\mathrm{N}=$ sampling frame and $\alpha$ represent the margin of error or confidence level.

The study uses a $95 \%$ confidence interval $(\alpha=0.05)$.

For the population (sampling frame) of 104, the sample size is determined as;

$n=\frac{104}{1+4104(0.05)^{2}}=\frac{104}{1+104(0.0025)}=\frac{104}{1.26}=83$.

The sample size of the study was therefore 83 individuals selected from the staff of Zoomlion, KMA waste management division and individual MSW collectors in the Kumasi Metropolis.In selecting the respondents of the study, a multistage sampling technique was employed. The selection of the Kumasi Metropolis was done purposively. Kumasi is the second largest city of Ghana with high level of commercial activities leading to large volumes of waste generation. The individuals (staff) from Zoomlion and the Waste Management Division of the KMA were selected by way of census since the numbers were relatively small (16 and 5 respectively). The individual waste collectors at the Metropolis were however selected using convenient sampling since they are scattered across the Metropolis and therefore difficult to assemble. Two main instruments were used in data collection viz. a questionnaire and interview guide. Data collected for the study were 
analysed using the Statistical Package for the Social Sciences (SPSS version 25) and Microsoft excel.

The energy potential of the landfill sites was estimated with respect to potential of biogas generation from both municipal solid and liquid waste disposed at the landfill site. The technical potential of biogas from Municipal Solid Waste (MSW) was estimated using the equation by Kemausuor et al. (2014) where Biogas from MSW is defined as the product of the amount of Municipal Solid Waste (QMSw), Concentration of Organic Fraction (COF MSw), Concentration of Total Solid $\left(\mathrm{C}_{\mathrm{Ts}}\right)$ and Bio-Methane Motential of the waste $\left(\mathrm{BMP}_{\text {of }} \mathrm{MSW}\right)$. The potential of biogas generation from Municipal Liquid Waste (MLW) was also estimated as the product of the quantity of liquid waste $\left(\mathrm{Q}_{\mathrm{MLW}}\right)$, concentration of total solid $\left(\mathrm{C}_{\mathrm{Ts}}\right)$ and the biomethane potential (BMP $\mathrm{BP}_{\text {of }}$ MLW). The two equations defining the potential of biogas generation from the solid and liquid waste deposited in the landfill sites are indicated in equation 1 and 2 respectively below;

Biogas $_{\mathrm{MSW}}=\mathrm{Q}_{\mathrm{MSW}} \times \mathrm{C}_{\mathrm{of}} \mathrm{MSW} \times \mathrm{C}_{\mathrm{Ts}} \times \mathrm{BMP}_{\mathrm{o}}$

Biogas $M L S=Q_{M L W} \times C_{T s} \times B P_{0}$

The total energy potential of the landfills sites was estimated as the sum of the potential of biogas generation from solid waste and that of liquid waste.

\section{Demographic Characteristics of the Respondents}

The demographic characteristics of the respondents collected and analysed are presented in Table 1. As the results show, 6(7.3\%) of the respondents were from the KMA Waste management department working at the KMA landfill site, 14(17.1\%) from Zoomlion Ghana limited and 62(75.6\%) were individual (private) waste collectors that did not work under any company at all. With regards to the specific roles respondents play along the waste management chain, the results show that the majority $(76.5 \%)$ of the respondents were made up of individuals involved in waste collection. A total of $13(15.9 \%)$ of the respondents play management roles in the waste management chain in the Kumasi Metropolis; 5(6.1\%) of the respondents play engineering/technical roles in the waste management chain whereas $2(2.4 \%)$ play supervisory and safety control roles in the waste management chain in the Kumasi Metropolis. Clearly, the results show a relative balance representation of key actors within the waste management chain in the Kumasi Metropolis.

In terms of education, the results show that nearly half $(46.3 \%)$ of the respondents had no formal education. The number of respondents with only basic school education were also 18, representing $22 \%$ of the respondents whereas $5(6.1 \%)$ had up to secondary school education. Only $4(4.9 \%)$ had tertiary (Master's Degree) education, 14 (17.1\%) have Bachelor degree and 3(3.7\%) have HND. No respondent had PhD certificate. Clearly the results show a significant number of respondents with no formal education. This group, which were mainly the individual waste collectors goes to support the findings by Owusu-Sekyere et al (2013) that individuals involved in waste collection in the Kumasi Metropolis are have very low formal education. The demographic characteristics of the respondents are presented in Table 1. 
Table 1: Demographic Characteristics of the Respondents

\begin{tabular}{llcc}
\hline Characteristic & Option/Response & Frequency & Percentage \\
\hline Organisation & KMA Landfill & 6 & 7.3 \\
& Zoom Lion Ghana & 14 & 17.1 \\
& None (Individuals) & 62 & 75.6 \\
Position/Role & Management/Administrative & 13 & 15.9 \\
& Engineering/Technical & 5 & 6.1 \\
& Safety and supervision & 2 & 2.4 \\
& Waste Collection & 62 & 75.6 \\
Length of service(yrs) & 5 or less years & 31 & 37.8 \\
& 6-10 years & 36 & 43.9 \\
Highest Education & 11-15 years & 15 & 18.3 \\
& No Formal Education & 38 & 46.3 \\
& Basic Education & 18 & 22.0 \\
& Secondary Education & 5 & 6.1 \\
& Post-Secondary (HND) & 3 & 3.7 \\
& Tertiary (First Degree) & 14 & 17.1 \\
& Tertiary (Masters) & 4 & 4.9 \\
\hline
\end{tabular}

Source: Field Survey (2017)

\section{Factors Hindering Waste to Energy Generation in the Kumasi Metropolis}

In the study, the respondents were asked to indicate the extent to which they agree that the factors identified hinder Waste to Energy generation using a 5-point Likert scale ( $\mathrm{SD}=\mathrm{Strongly}$ Disagree, $\mathrm{D}=$ Disagree, $\mathrm{N}=$ Neutral, $\mathrm{A}=$ Agree and $\mathrm{SA}=$ Strongly Agree). The results from analysis of responses gathered are presented in Table 2. From the results, it is observed that the majority (54.9\%) of the respondents strongly disagree that unavailability of significant quantity of waste for energy generation is a factor that hinder waste to energy generation. The results clearly indicate that most of the respondents observe that the amount of waste generated in the Kumasi Metropolis is significant for waste to energy generation. This finding is consonance with past studies such as Ofori (2016), Kemausour et al. (2014) among others that have observed that the amount of waste generated in the cities of Ghana are significant for waste to energy generation. With regards to capital cost and operational cost of operating waste to energy plants, the results from the analysis clearly give an indication that most respondents consider waste to energy generation as an expensive and capital-intensive investment. Cumulatively 48(59.8\%) of the respondents agreed or strongly agreed that high cost of capital is factor that hinder energy to waste generation. Nearly half (43.9\%) of the respondent have also agreed high operational cost is a hindrance to waste to energy generation with $25(30.5 \%)$ responding strongly agree and no respondent indicating that they disagree. The results clearly show that the individuals in the waste collection and management chain of the Kumasi Metropolis have the idea that operating waste to energy plants is an expensive and capital-intensive business. This observation confirms Rodríguez (2011) claim that high capital cost of waste to energy plants remain a major challenging factor affecting the development of 
waste to energy technologies particularly in developing countries. The results also go to indicate that Ellyin and Themelis (2011) observation that investors in Waste to energy generation have financial difficulties that impede the smooth implementation of waste to energy generation is tenable as the result of this study have shown. The results also show that the high proportions of the respondents were neutral about the availability of technical expertise and profitability of waste to energy facilitates ( $29.3 \%$ and $45.1 \%$ respectively). This is due to the fact that, there is currently none of such facilities to enable respondents come to conclusion whether there is expertise and how profitable such a venture can be. Zhang et al. (2010) have indicated that, most developing countries especially in Africa are not able to effectively and efficiently develop waste management strategies as a result of lack of technical expertise. The results of the study however did not support nor justified this observation as the majority of the respondents were neutral on the availability of technical expertise in Ghana and the Kumasi Metropolis in particular. Lack of governmental support and policy framework to support waste to energy generation was also subscribed to by many respondents. Cumulatively, $50.1 \%$ of the respondents either agreed or strongly agreed that there is lack of governmental support for waste to energy plants, whereas $29.2 \%$ either agreed or strongly disagree that there is lack of policy framework for waste to energy generation with $40.2 \%$ indicating neutral to the statement.

Table 2: Respondents Perceptions on Factors That Hinder Waste to Energy Generation

\begin{tabular}{|c|c|c|c|c|c|}
\hline Factor & SD & $\mathrm{D}$ & $\mathrm{N}$ & $\mathrm{A}$ & SA \\
\hline $\begin{array}{l}\text { Unavailability of significant quantity of waste for energy } \\
\text { generation }\end{array}$ & $\begin{array}{c}45 \\
(54.9)\end{array}$ & $\begin{array}{c}20 \\
(24.4)\end{array}$ & $\begin{array}{c}9 \\
(11.0)\end{array}$ & $\begin{array}{c}4 \\
(4.9)\end{array}$ & $\begin{array}{c}4 \\
(4.9)\end{array}$ \\
\hline High capital cost of waste to energy plants & $\begin{array}{c}0 \\
(0)\end{array}$ & $\begin{array}{c}21 \\
(25.6)\end{array}$ & $\begin{array}{c}12 \\
(14.6)\end{array}$ & $\begin{array}{c}25 \\
(30.5)\end{array}$ & $\begin{array}{c}24 \\
(29.3)\end{array}$ \\
\hline High operational costs involve in waste to energy plants & $\begin{array}{c}0 \\
(0)\end{array}$ & $\begin{array}{c}0 \\
(0)\end{array}$ & $\begin{array}{c}21 \\
(25.6)\end{array}$ & $\begin{array}{c}36 \\
(43.9)\end{array}$ & $\begin{array}{c}25 \\
(30.5)\end{array}$ \\
\hline $\begin{array}{l}\text { Lack of technical expertise to manage waste to energy } \\
\text { plants }\end{array}$ & $\begin{array}{c}8 \\
(9.8)\end{array}$ & $\begin{array}{c}20 \\
(24.4)\end{array}$ & $\begin{array}{c}24 \\
(29.3)\end{array}$ & $\begin{array}{c}25 \\
(30.5)\end{array}$ & $\begin{array}{c}5 \\
(6.1)\end{array}$ \\
\hline Low return or profitability of waste to energy generation & $\begin{array}{c}17 \\
(20.7)\end{array}$ & $\begin{array}{c}20 \\
(24.4)\end{array}$ & $\begin{array}{c}37 \\
(45.1)\end{array}$ & $\begin{array}{c}0 \\
(0)\end{array}$ & $\begin{array}{c}8 \\
(9.8)\end{array}$ \\
\hline Lack of governmental support for waste to energy plants & $\begin{array}{c}17 \\
(20.7)\end{array}$ & $\begin{array}{c}8 \\
(9.8)\end{array}$ & $\begin{array}{c}20 \\
(24.4)\end{array}$ & $\begin{array}{c}25 \\
(30.5)\end{array}$ & $\begin{array}{c}12 \\
(14.6)\end{array}$ \\
\hline $\begin{array}{l}\text { Lack of policy framework to promote waste to energy } \\
\text { generation }\end{array}$ & $\begin{array}{c}12 \\
(14.6)\end{array}$ & $\begin{array}{c}13 \\
(15.9)\end{array}$ & $\begin{array}{c}33 \\
(40.2)\end{array}$ & $\begin{array}{c}12 \\
(14.6)\end{array}$ & $\begin{array}{c}12 \\
(14.6)\end{array}$ \\
\hline
\end{tabular}




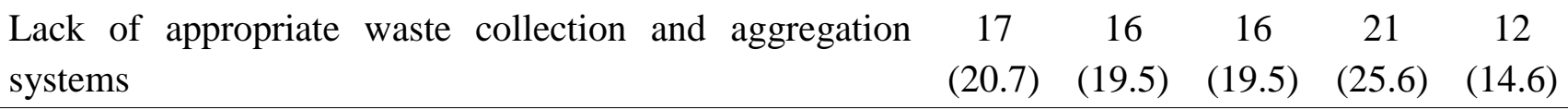

Source: Field Data (2017)

\section{Waste Characteristics and Disposal Methods in the Kumasi Metropolis}

The study examines the characteristics of waste that are collected by respondents in the Kumasi Metropolis and the means through which the waste has been disposed. The characteristics of waste collected in the Kumasi Metropolis as identified in the study include biodegradable waste (food and kitchen waste, green waste), Recyclable materials (paper, cardboard, glass, bottles, jars, tin cans), Inert waste (construction and demolition waste, dirt, rocks, debris), Electrical and electronic waste (electrical appliances, bulbs, washing machines, TVs, computers, screens, mobile phones, alarm clocks, watches) Hazardous waste ( paints, chemicals, tires, batteries, light bulbs, electrical appliances, fluorescent lamps, aerosol spray cans, and fertilizers), Toxic waste (pesticides, herbicides, and fungicides) and Biomedical waste, (expired pharmaceutical drugs).

\section{Characteristics of Waste Collected by Individual Waste Collectors}

The results on the extent to which waste collected by respondents contain various categories of waste substances are presented in Table 3. As the results show, no respondent indicated that waste collected did not include biodegradable waste (organic materials) and recyclable materials. The majority (54.8\%) of the respondents have indicated that the waste they collect have very high biodegradable components. This confirms Asase et al. (2009) and Meiza et al. (2015) assertion that most MSW in Ghana contain high concentration of organic materials which are significant for energy generation. About a quarter of the respondents also indicated that recyclable materials compositions in the waste they collect are very low. The results also show that most respondents collect waste that contain medium to low composition of Inert waste, electrical and electronic waste, hazardous waste, toxic waste and biomedical waste. In all 3(4.8\%), 3(4.8\%), 14(22.6\%), $14(22.6 \%)$ and $10(16.1 \%)$ of the respondents indicated that the waste they collect in the Kumasi metropolis does not contain inert waste, electrical and electronic waste, hazardous waste, toxic waste and biomedical waste respectively.

The results generally reflect results from previous studies on the composition of waste in the Kumasi metropolis and in Ghana in general. In separate studies by Asase et al., (2009), Meiza et al. (2015) and Ofori (2016), biodegradable waste including food and other organic materials have been identified to constitute the largest portion of the total MSW in Ghana. Meiza et al. (2015) estimated the organic fraction of MSW in Ghana to be between ranges of $61 \%$ to $64 \%$. Wastes with high organic fraction are indicative of great potential for energy generation (Ofori, 2016). This implies that, there is available feed stock for waste to energy generation based on the composition of waste generated in the Kumasi Metropolis. Table 3 presents the respondents' view on the composition of waste they collect in the Kumasi Metropolis. 
Table 3: Characteristics of Wastes collected in the Kumasi Metropolis

\begin{tabular}{|c|c|c|c|c|c|c|}
\hline Characteristics & None & $\begin{array}{l}\text { Very } \\
\text { Low }\end{array}$ & Low & Average & High & $\begin{array}{l}\text { Very } \\
\text { High }\end{array}$ \\
\hline Biodegradable waste & 0 & $\overline{0}$ & $3(4.8)$ & $12(19.4)$ & $13(21)$ & $34(54.8)$ \\
\hline Recyclable materials & 0 & $6(9.7)$ & $16(25.8)$ & $18(29)$ & $9(14.5)$ & $13(21)$ \\
\hline Inert waste & $3(4.8)$ & $19(30.6)$ & $31(50)$ & $9(14.5)$ & 0 & 0 \\
\hline $\begin{array}{l}\text { Electrical and electronic } \\
\text { waste }\end{array}$ & $3(4.8)$ & $22(35.4)$ & $31(50)$ & $3(4.8)$ & $3(4.8)$ & $3(4.8)$ \\
\hline Hazardous waste & $14(22.6)$ & $18(29)$ & 21(33.9) & $9(1$ & 0 & 0 \\
\hline Toxic waste & $14(22.6)$ & $24(38.7)$ & $15(24.2)$ & $9(14.5)$ & 0 & 0 \\
\hline Biomedical waste & $10(16.1)$ & $18(29)$ & $22(35.5)$ & $9(14.5)$ & 0 & $3(4.8)$ \\
\hline
\end{tabular}

Source: Field Survey (2016) (Figures in parenthesis are percentages)

\section{Total Quantities of Waste Collected Annually in the Kumasi Metropolis}

The ability to generate energy from waste is dependent not only on the composition, but the quantity of the waste generated as well. While there is very limited data on the total waste generated in the Kumasi Metropolis, waste collected and received at the KMA landfill site has been recorded by the Waste Management division of the KMA at Oti. The results from analysis of the data on waste collected and received at the Landfill site is presented in Figure 1. As the results show, there have been increasing quantities of waste collected in the Kumasi Metropolis over the years. Apart from 2010 when the total quantity of MSW collected dropped from 442, 062 metric tonnes to 414, 360 metric tonnes, over the entire period MSW collected has increased consistently. While this may be due to increased efforts in collection the rate of increase in population also account for the large quantities of MSW collected over the period. The trend of quantities of waste collected in Kumasi and received at the Landfill site is presented in Figure 1 below. 


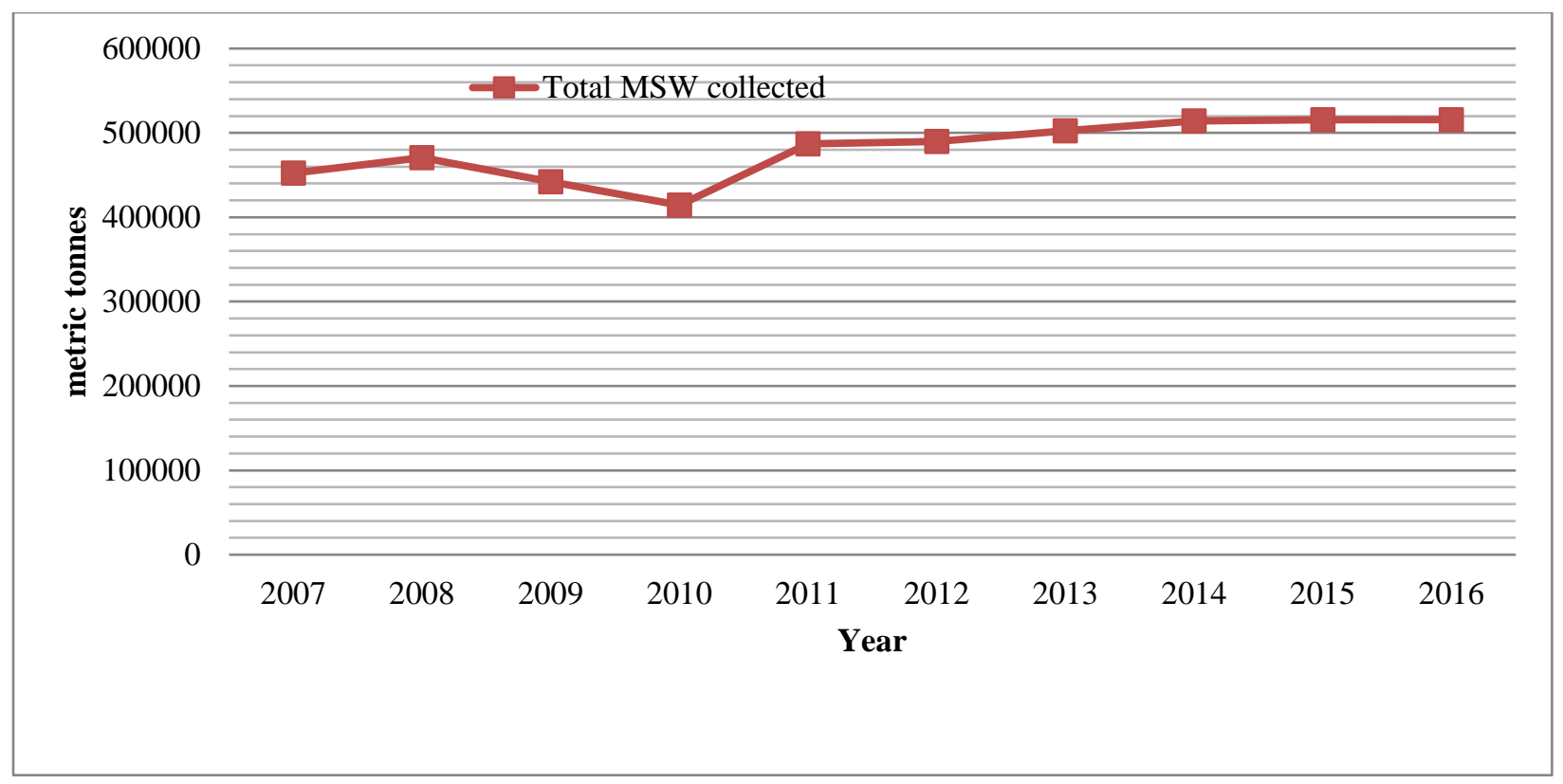

Fig. 1: Total quantity of MSW collected in the Kumasi Metropolis Source: Waste Management Department of Kumasi Metropolitan Assembly [KMA] (2017)

\section{Total quantity of MSW generated in the Kumasi Metropolis per year}

Due to the absence of data on total waste generation in the Kumasi Metropolis, an estimate of $0.47 \mathrm{~kg} /$ person/day obtained from a survey by Meiza et al. (2015) was used in the study. The UN World Cities records (2016) estimated the population of Kumasi to 2,718,000 people and will grow at a rate of $3.1 \%$ from 2016 to 2030 . Given the per person rate of waste generation reported by Meiza et al. (2015) to $0.47 \mathrm{~kg}$, it means the daily MSW generated in the Kumasi Metropolis was 1277.46 metric tonnes.

The results in Table 4 show an estimated daily and annual waste generation using the estimated population growth rate of 3.1 and per person waste generation of $0.47 \mathrm{~kg} / \mathrm{day}$. As shown in the results, the estimated daily waste generation will reach 1534 metric tons per day by 2022 and 1787.28 metric tons ten (10) years from now. With increasing population and urbanization, the rate of waste generation may increase beyond $0.47 \mathrm{~kg} /$ person/day and that will result in higher waste generation daily. As the quantity of waste generated increase with increase in population, the estimated daily waste generation will increase until population growth turns negative. As population continues to increase, the quantity of waste generated in the Kumasi Metropolis could continue to increase at increasing rate for long. 
Table 4: Estimated daily waste generation in the Kumasi Metropolis

\begin{tabular}{lccc}
\hline Year & $\begin{array}{c}\text { Population* } \\
\text { (Estimate base on growth rate } \\
\text { of 3.1\%) }\end{array}$ & $\begin{array}{c}\text { Daily waste } \\
\text { generation* (metric } \\
\text { tons) }\end{array}$ & $\begin{array}{c}\text { Projected } \\
\text { Annual } \\
\text { waste } \\
\text { generation }\end{array}$ \\
\hline $\mathbf{2 0 1 7}$ & 2802258 & 1317.06 & 480726.9 \\
$\mathbf{2 0 1 8}$ & 2889128 & 1357.89 & 495629.9 \\
$\mathbf{2 0 1 9}$ & 2978691 & 1399.98 & 510992.7 \\
$\mathbf{2 0 2 0}$ & 3071030 & 1443.38 & 526833.7 \\
$\mathbf{2 0 2 1}$ & 3166232 & 1488.13 & 543167.5 \\
$\mathbf{2 0 2 2}$ & 3264386 & 1534.26 & 560004.9 \\
$\mathbf{2 0 2 3}$ & 3365581 & 1581.82 & 577364.3 \\
$\mathbf{2 0 2 4}$ & 3469915 & 1630.86 & 595263.9 \\
$\mathbf{2 0 2 5}$ & 3577482 & 1681.42 & 613718.3 \\
$\mathbf{2 0 2 6}$ & 3688384 & 1733.54 & 632742.1 \\
$\mathbf{2 0 2 7}$ & 3802724 & 1787.28 & 652357.2 \\
\hline
\end{tabular}

Source: Author's estimation (2017)

\section{Waste Disposal Methods Used by Waste Collectors}

From the results of the analysis as presented in Table 5, the majority (96.3\%) of the respondents indicated that waste they collect are disposed of at the landfill site. A few (3) representing $3.7 \%$ of the respondents indicated that they disposed of their waste at any place of convenience to them. According to Parrot et al. (2009), the most common waste management practice among African cities is composting. The results from this study however contradict this observation as landfilling was found to be the commonest.

When respondents were asked to indicate the best means through which waste should be disposed, the majority (69.5\%) indicated energy recovery. Among the remainder of the respondents, 16 (19.5\%) indicated composting (production of manure) was the best means to disposed waste while 9(11\%) indicated landfill site. This observation indicates that though landfilling is the commonly practiced means of waste disposal, most respondents believe energy recovery is much more appropriate. Tanskanen (2000) noted that there is increasing recognition of energy to waste generation as alternative to landfilling not only in developed countries but developing countries as well. The finding of this study shows that this recognition is held by the waste management actors of the Kumasi Metropolis. Leskens et al. (2005) have noted that the process of Waste to energy generation has very little impact on the environment. The findings from the responses show that respondents were knowledgeable of positives of waste energy generation as a more environmentally friendly means of waste management. 
Table 5: Waste Disposal practice and respondents' opinion on best practice

\begin{tabular}{lcc}
\hline Waste Disposal Methods & $\begin{array}{c}\text { Number of } \\
\text { Respondents } \\
\text { Practicing } \\
\text { this method }\end{array}$ & $\begin{array}{c}\text { Best Methods in } \\
\text { Respondents View }\end{array}$ \\
\hline Incineration & 0 & $57(69.5)$ \\
Energy recovery & 0 & $9(11)$ \\
Left in landfill forever & $79(96.3)$ & 0 \\
Disposed of into the sea & 0 & $16(19.5)$ \\
Composting (production of manure) & 0 & 0 \\
Disposed at any place of Convenience & $3(3.7)$ & \\
\hline Source: Field Survey (2017) & (figures in parenthesis are percentages)
\end{tabular}

\section{Energy Potential of Waste generated and Collected in the Kumasi Metropolis}

The energy potential of the MSW in the Kumasi Metropolis was estimated with respect to potential biogas generation from the waste given the characteristics and quantities. An equation by Kemausuor et al. (2014) given as Biogas ${ }_{\mathrm{MSW}}=\mathrm{Q}_{\mathrm{MSW}} \times \mathrm{C}_{\mathrm{of}} \mathrm{MSW} \times \mathrm{C}_{\mathrm{Ts}} \times \mathrm{BMP}_{\text {of }} \mathrm{MSw}$ Where

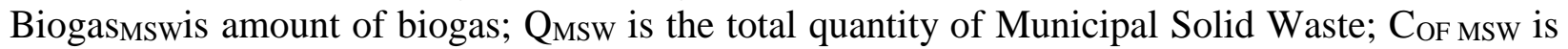
the organic fraction of the waste; $\mathrm{C}_{\mathrm{Ts}}$ is the concentration of total solid and $\mathrm{BMP}_{\text {of }}$ MSw is biomethane potential of the waste. The parameters in the equation were obtained from available records at the Waste Management Division of the KMA and reports from experimental studies using MSW in the Ghana. The organic fraction of MSW in most studies conducted ranges between 61 to $64 \%$. The study used an organic fraction ( $\mathrm{COF}$ ) of 64\% reported by Asase et al. (2009) which was confirmed by the manager of the KMA landfill (Reverend Morrison) site as an appropriate estimation of the organic fraction of waste in the Kumasi Metropolis. BMP of MSw was also taken from Gunnaseelan (1997) to be $0.32 \mathrm{~m}^{3} \mathrm{CH}_{4} / \mathrm{KgTs}$ while the Total Solid Concentration $\left(\mathrm{C}_{\mathrm{Ts}}\right)$ was taken from estimate of Kemausour et al. (2014). To ensure accuracy and validity, Renewable Energy Experts and Energy Consultants at the Energy Center of the Kwame Nkrumah University of Science and Technology were contacted to verify the accuracy of the estimates before analysis was performed. The calorific value (energy potential) of biogas from the estimation of Ofori (2016) and Kemausour et al. (2014) is about $36 \mathrm{MJ} / \mathrm{m}^{3}$, meaning that $1 \mathrm{~m}^{3}$ of biogas corresponds to an energy content of about $10 \mathrm{~kW} / \mathrm{h}$. The efficiency of converting the potential energy into electricity according to Murphy et al. (2004) is 35\% and 40\% for thermal conversion. This implies for every $1 \mathrm{kWh}$ of potential energy, $0.35 \mathrm{kWh}$ of electricity can be generated. The results as presented in Table 5 show the potential energy that could be generated from MSW collected in the Kumasi Metropolis annually from 2007 to 2016. From the results, it can be observed that the biogas potential of MSW collected at the Kumasi Metropolis in 2007 was 50.31 million $\mathrm{m}^{3}$ which could give potential energy of $1.805 \mathrm{PJ}$ and $175.457 \mathrm{GW} / \mathrm{h}$ of electricity flow. The national residential energy consumption as reported by the Energy commission (Energy Commission, 2013) was 2,095GW/h in 2007. This means that if the MSW produced in Kumasi alone were converted into energy, it could serve $8 \%$ of national residential electricity consumption. From the results in Table 4.6, it can be observed that in 2016, the MSW collected in the Kumasi Metropolis could generate a potential energy of $2.057 \mathrm{PJ}$ with conversion efficiency of $35 \%$, potential electricity of $0.72 \mathrm{PJ} / \mathrm{yr}$ 
could be harnessed with electric power flow of about $200 \mathrm{GW} / \mathrm{h}$. This figure is very significant considering the fact that the total residential energy consumption of Ghana in 2015 was 2,437GW/h (Energy Commission, 2015). Ofori (2016) estimated the energy potential of MSW generated in Ghana in 2016 to be $18.5 \mathrm{PJ}$ which could satisfy $17 \%$ of the electricity consumption of the country. The results of this study show that the Kumasi Metropolis alone could contribute to $11.1 \%$ of the potential energy that could be generated nationally. The results have supported claims that MSW in Ghana are rich in energy and if harnessed could contribute significantly to reducing the energy deficit of Ghana. The results show that Waste generated in the Kumasi Metropolis if converted to energy could contribute to $8-10 \%$ of national residential electricity consumption. These findings also resonate with the findings of Ofori (2016) that MSW in Ghana alone could produce $17 \%$ of total energy demand of the country. The findings imply that by converting waste to energy, improving conversion efficiency, there could be a reduction in the energy deficit of Ghana. The results; potential biogas value, potential energy, potential electric capacity and estimated electric power flow of MSW generated and collected in the Kumasi Metropolis from 2007 to 2016 are presented in Table 6.

Table 6: Energy and electricity potential MSW collected in KMA (2007-2016)

\begin{tabular}{|c|c|c|c|c|c|}
\hline Year & $\begin{array}{c}\text { Qty of MSW } \\
\text { (Metric tons } \\
\text { t/yr) }\end{array}$ & $\begin{array}{c}\text { Potential* } \\
\text { Biogas } \\
\left(\text { Million m }^{3}\right) \text { of } \\
\text { CH4/yr }\end{array}$ & $\begin{array}{c}\text { Potential* } \\
\text { energy } \\
\text { (PJ/yr) }\end{array}$ & $\begin{array}{c}\text { Potential* } \\
\text { Electricity } \\
\text { (PJ/yr) }\end{array}$ & $\begin{array}{c}\text { Electricity* } \\
\text { flow } \\
(\text { GW/h) }\end{array}$ \\
\hline 2007 & 452456 & $\begin{array}{l}50.13 \\
\end{array}$ & 1.805 & 0.632 & 175.457 \\
\hline 2008 & 470620 & 52.14 & 1.877 & 0.657 & 182.501 \\
\hline 2009 & 442062 & 48.98 & 1.763 & 0.617 & 171.427 \\
\hline 2010 & 414360 & 45.91 & 1.653 & 0.578 & 160.684 \\
\hline 2011 & 486891 & 53.95 & 1.942 & 0.680 & 188.811 \\
\hline 2012 & 489943 & 54.28 & 1.954 & 0.684 & 189.994 \\
\hline 2013 & 502247 & 55.65 & 2.003 & 0.701 & 194.766 \\
\hline 2014 & 514376 & 56.99 & 2.052 & 0.718 & 199.469 \\
\hline 2015 & 515340 & 57.10 & 2.056 & 0.719 & 199.843 \\
\hline 2016 & 515700 & 57.14 & 2.057 & 0.720 & 199.983 \\
\hline Total & 4803995 & 532.27 & 19.162 & 6.706 & 1862.935 \\
\hline
\end{tabular}

Source: Field Data (2017)

(*denotes estimated figures)

\section{Conclusion and Recommendation}

The use of Municipal Solid Waste (MSW) for energy generation has been one such a novel technology that is gaining recognition worldwide. The technology is much more admirable because not only will it contribute to solving waste management situation in most cities but also generate revenue and help close the energy deficit most developing countries are grabbling with. The results showed that several factors hinder waste to energy technology in Ghana; key among them were high capital cost, high operational cost and lack of governmental support and policy framework. The results also revealed that $1 \mathrm{~m}^{3}$ of biogas generated from MSW in Kumasi could 
generate $36 \mathrm{MJ}$ of energy, equivalent to $10 \mathrm{~kW} / \mathrm{h}$. The findings of this study largely support the assertion that urban/ domestic waste presents a good potential for the purpose of energy generation. The organic fraction of MSW in the Kumasi Metropolis and the quantity of waste collected daily gives an indication of good potential energy content. This paper offers an innovative analytical and methodological approach in determining the potential of waste to energy generation. The unique contribution made by the paper is that it combines expert opinions, empirical data that included time series data and opinion of key actors in the waste management chain in assessing the potential for waste to energy generation in the Kumasi Metropolis of Ghana. This paper also provides guide for investors and policy makers in the waste management industry. Theoretically, the findings of this study will provide a database to adopt the concept of Waste to energy projects in Kumasi and the surrounding cities/towns. The study therefore recommends the establishment of Waste to Energy plant in the Kumasi Metropolis. Contextually, the paper is limited to assessing the energy potentials of MSW and the factors that affect energy generation from waste in the Kumasi Metropolis. Future research should focus on analysis of the economic viability of Wasteto-Energy generation in the Kumasi Metropolis of Ghana.

\section{References}

Acheampong, M., Yu, Q., Cansu Ertem, F., Deba Enomah Ebude, L., Tanim, S., Eduful, M., Vaziri, M. and Ananga, E., 2019. Is Ghana Ready to Attain Sustainable Development Goal (SDG) Number 7? - A Comprehensive Assessment of Its Renewable Energy Potential and Pitfalls. Energies, 12(3), 408.

Ackom, E. (2013). West African electrification: Complementary Options Using Sustainably Derived Biomass, Accra. Paper presented at The Power and Electricity West Africa Conference, Accra, Ghana.

Agbelie,I., Bawakyillenuo,S., and Lemaire, X (2015).Waste-to-energy: African cities can transform their energy landscapes. Retrieved January, 30, 2017 from https://www.urbanafrica.net/urban-voices/waste-to-energy-african-cities-can-transformtheir-energy-landscapes/.

Akolgo, G.A., Essandoh, E.O., Gyamfi, S., Atta-Darkwa, T., Kumi, E.N. and de Freitas Maia, C.M.B., 2018. The potential of a dual purpose improved cookstove for low income earners in Ghana-Improved cooking methods and biochar production. Renewable and Sustainable Energy Reviews, 82, 369-379.

Arthur, R., Baidoo, M. F., and Antwi, E. (2011). Biogas as a potential renewable energy source: A Ghanaian case study. Renewable Energy, 36(5), 1510-1516.

Asase, M., Yanful, E.K., Mensah, M., Stanford, J., and Amponsah S. (2009). Comparison of municipal solid waste management systems in Canada and Ghana: a case study of the cities of London, Ontario, and Kumasi, Ghana. Waste Management, 29(10), 79-86.

Bawakyillenuo, S. and Agbelie, I.K. (2014). Waste as a Resource for Energy Generation in the Ga East and Awutu Senya East Municipalities: The Policy Discourse. University of Ghana, SAMSET project, 2014. Retrieved January, 30, 2017 from http://samsetproject.site11.com/outputs/. 
Bello, I. A., Ismail, M. N., and Kabbashi, N. A. (2016). Solid waste management in Africa: A review. International Journal of Waste Resources, 6(2), 1-4.

Bensah, E. C., and Brew-Hammond, A. (2010). Biogas technology dissemination in Ghana: history, current status, future prospects, and policy significance. International Journal of Energy and Environment, 1(2), 277-294.

Chibinda, D. (2016). Municipal solid waste in a circular economy perspective: A case study of Lusaka City in Zambia. Unpublished Master's Thesis submitted to the Swedish University of Agricultural Science.

Danquah, J.A., Roberts, C.O. and Appiah, M., 2018. Elephant Grass (Pennisetum purpureum): A Potential Source of Biomass for Power Generation in Ghana. Current Journal of Applied Science and Technology, 1-12.

Duku, M. H., Gu, S., and Hagan, E. B. (2011a). A comprehensive review of biomass resources and biofuels potential in Ghana. Renewable and sustainable energy reviews, 15(1), 404415.

Duku, M. H., Gu, S., and Hagan, E. B. (2011b). Biochar production potential in Ghana-A review. Renewable and Sustainable Energy Reviews, 15(8), 3539-3551.

Economic Commission for Africa [ECA] (2009). Africa Review Report on Waste Management. Committee on Food Security and Sustainable Development Regional Implementation Meeting for CSD-18 -Sixth Session. E/ECA/CFSSD/6/9, Accessed: 12/3/2017.

Ellyin, C., and Themelis, N. J. (2011, January). Small scale waste-to-energy technologies. In 19th Annual North American Waste-to-Energy Conference (pp. 169-176). American Society of Mechanical Engineers.

Energy Commission [EC] (2006). Strategic national energy plan (2006-2020) and Ghana energy policy. Accra, Ghana: Main version.

Environmental Services Association [ESA](2013). How waste work. Retrieved January 21,2017 from http://www.esauk.org/how_waste_works/, Accessed: 21/03/2017.

European Parliament (2017). Towards a circular economy -Waste management in the EU.www.europarl.europa.eu/RegData/etudes/STUD/.../EPRS_STU(2017)581913_EN.pd f (Accessed, February 27, 2018).

Fobil, J. N. (2002). Proceedings of International Symposium on Environmental Pollution Control and Waste Management 7-10 January 2002, Tunis (EPCOWM'2002), 193-205.

Gyamfi, S., Modjinou, M. and Djordjevic, S., 2015. Improving electricity supply security in Ghana-The potential of renewable energy. Renewable and sustainable energy reviews, 43, 1035-1045.

Gomaa, M.R., Al-Dmour, N., AL-Rawashdeh, H.A. and Shalby, M., (2020). Theoretical model of a fluidized bed solar reactor design with the aid of MCRT method and synthesis gas production. Renewable Energy, 148, pp.91-102. https://doi.org/10.1016/j.renene.2019.12.010. 
Gomaa, M.R., Mustafa, R.J. and Al-Dmour, N., (2020). Solar thermochemical conversion of carbonaceous materials into syngas by Co-Gasification. Journal of Cleaner Production, 248, pp.119185. https://doi.org/10.1016/j.jclepro.2019.119185.

International Energy Agency (IEA) (2007). Renewables in global energy supply. Paris:IEA.

International Renewable Energy Agency (2015). International renewable Energy AgencyProspects for the African Power Sector. Retrieved January 30, 2017. From https://www.irena.org/DocumentDownloads/Publications/Prospects_for_the_African_Po werSector.pdf.

Kemausuor, F., Kamp, A., Thomsen, S. T., Bensah, E. C., and Østergård, H. (2014). Assessment of biomass residue availability and bioenergy yields in Ghana. Resources, Conservation and Recycling, 86, 28-37.

Leskens M, Kessel, L.B.M.V., and Bosgra O.H. (2005) Model predictive control as a tool for improving the process operation of MSW combustion plants. Waste Management, 25 (7), 88-98.

Mack, J. W., Hilden, J. M., Watterson, J., Moore, C., Turner, B., Grier, H. E., and Wolfe, J. (2005). Parent and physician perspectives on quality of care at the end of life in children with cancer. Journal of Clinical Oncology, 23(36), 9155-9161.

Meiza, K., Obiri-Danso, K., Kadar, Z., Fei-Baffoe, B., and Mensah, M. Y. (2015) Municipal solid waste characterization and quantification as a measure towards effective waste management in Ghana, Waste Management, 46,15-27.

Menikpura, S.N.M, Sang-Arun, J., and Bengtsson, M. (2016). Assessment of environmental and economic performance of Waste-to-Energy facilities in Thai cities, Renewable Energy .86, 576-584.

Mohammed, Y.S., Mokhtar, A.S., Bashir, N., and Saidur, R. (2013). An overview of agricultural biomass for decentralized rural energy in Ghana, Renewable and Sustainable Energy Reviews20, 15-22.

Niwagaba C. (2007). Human excreta treatment technologies e prerequisites, constraints and performance. Institution enförbiometriochteknik. Department of Biometry and Engineering; ISSN 1652-3261.

Obour, S.K. (2012). “Accra Sinks under Filth”. The Mirror, Saturday, September 15, 2012, pp.24.

Ofori, G. M. L. (2016). Waste to Energy: an alternate energy source for Ghana. A thesis submitted to the School of Economic management, Lund University for the award of Master programme in Economic Growth, Innovation and Spatial Dynamics.

Ofori-Boateng, C., Lee, K.T., and Mensah, M. (2013). The prospects of electricity generation from municipal solid waste (MSW) in Ghana: A better waste management option, Fuel Processing Technology, 110, 94-102.

Owusu-Sekyere, E., Osumanu, I. K., and Yaro, J. A. (2013). Dompoase Landfill in the Kumasi Metropolitan Area of Ghana: A 'Blessing'or a 'Curse'? Int. J. Cur. Tr. Res (2013`1) 2(1), 87-96. 
Parrot, L., Sotamenou, J., and Dia, B. K. (2009). Municipal solid waste management in Africa: Strategies and livelihoods in Yaoundé, Cameroon. Waste management, 29(2), 986-995.

Ragossnig, A. M., Wartha, C., and Kirchner, A. (2008). Energy efficiency in waste-to-energy and its relevance with regard to climate control. Waste Management \& Research, 26(1), 70-77.

Ramachandra, T.V. (2008): Geographical information system approach for regional biogas potential assessment, Research Journal of environmental sciences, 2(3), 170-184.

Rodríguez, M. E. D. B. (2011). Cost-benefit analysis of a waste to energy plant for Montevideo; and waste to energy in small islands (Doctoral dissertation, COLUMBIA UNIVERSITY).

The World Bank (2012). What a waste. A global review of solid waste management. The Urban Development Series Knowledge papers. Washington DC, USA 2012.

Ulrike D., Karl-Heinz P., and Nayina, S.G. (2014). Biogas In Ghana - Sub-Sector Analysis Of Potential And Framework Conditions, retrieve January, 28, 2017 from http://www.renewables-made-in-germany.com.

Un-Habitat (2014). Note on Urbanisation Challenges, Waste Management, and Development, Mauritius. $\quad$ Retrieved January 30, 2017, from http://www.europarl.europa.eu/intcoop/acp/2014_mauritius/pdf/un_habitat_presentation_ en.pdf.

Zhang, D. Q., Tan, S. K., and Gersberg, R. M. (2010). Municipal solid waste management in China: status, problems and challenges. Journal of Environmental Management, 91(8), 1623-1633. 